\title{
Influence of Intercropping and Weed Management Practices on Weed Parameters and Yield of Maize
}

\author{
Ishaq Rahimi, M. Mohamed Amanullah, T. Ananthi and G. Mariappan* \\ Department of Agronomy, Tamil Nadu Agricultural University, Coimbatore, India \\ *Corresponding author
}

\begin{tabular}{|c|}
\hline Keywords \\
\hline $\begin{array}{l}\text { Maize, } \\
\text { Intercropping, } \\
\text { Weed control, } \\
\text { Pendimethalin, } \\
\text { Imazethapyr, Yield }\end{array}$ \\
\hline Article Info \\
\hline $\begin{array}{l}\text { Accepted: } \\
17 \text { March } 2019 \\
\text { Available Online: } \\
10 \text { April } 2019\end{array}$ \\
\hline
\end{tabular}

A B S T R A C T

A field experiment was conducted at Tamil Nadu Agricultural University, Coimbatore during kharif 2015 to investigate the influence of intercropping systems and weed management practices on weed density, dry weight and weed control efficiency in maize under irrigated condition. The experiment was laid out in split plot design and replicated thrice. Three intercropping systems viz., maize alone $\left(\mathrm{I}_{1}\right)$, maize + blackgram (1:1 ratio) $\left(\mathrm{I}_{2}\right)$ and maize + blackgram (2:2 ratio) $\left(\mathrm{I}_{3}\right)$ were evaluated under main plot and four weed management practices viz., unweeded check (Control) $9\left(\mathrm{~W}_{1}\right)$, Pendimethalin $0.75 \mathrm{~kg} \mathrm{ha}^{-1}$ as pre emergence (PE) $3 \mathrm{DAS}+$ one hand weeding at $25 \mathrm{DAS}\left(\mathrm{W}_{2}\right)$, Imazethapyr $75 \mathrm{~g} \mathrm{ha}^{-1}$ as post emergence (POE) 25 DAS $\left(\mathrm{W}_{3}\right)$ and Pendimethalin $0.75 \mathrm{~kg} \mathrm{ha}^{-1}$ as PE 3 DAS + Imazethapyr $75 \mathrm{~g} \mathrm{ha}^{-1}$ as POE 25 DAS $\left(\mathrm{W}_{4}\right)$ were accommodated under subplot. Observations on weed parameters viz., weed density, weed dry weight and weed control efficiency were recorded. The results of the experiment revealed that among the intercropping systems, maize + blackgram (1:1) intercropping and among weed management practices, pendimethalin $0.75 \mathrm{~kg} \mathrm{ha}^{-1}$ as PE 3 DAS + one HW 25 DAS recorded lesser total weed density and weed dry weight. Maize + blackgram intercropping along with pendimethalin $0.75 \mathrm{~kg} \mathrm{ha}^{-1}$ as PE 3 DAS + one HW 25 DAS recorded higher weed control efficiency. The sole crop of maize recorded higher yield than maize under intercropping systems followed maize + blackgram intercropping at 1:1 ratio.

\section{Introduction}

Maize (Zea mays L.) is the third most important cereal next to rice and wheat, in the world as well in India. It is a versatile crop and can be grown in diverse environmental conditions and has multiple uses. Many factors are responsible for the low yields of maize in India. Of the several factors, most critical for the low yield appears to be the weed growth that competes with the crop for nutrients, water, sunlight and space. They cause yield losses worldwide with an average of 12.8 per cent despite weed control practices and $29.2 \%$ in case of unchecked weed growth (Dogan et al., 2004). Although maize plant is vigorous and tall in nature, yet it is very sensitive to weed competition at early stages of growth. Hence, it is necessary that maize should be kept free of weeds for the first 30 days after crop emergence. 
Weeding has traditionally been a labour intensive operation in crop production. Manual weeding is seldom possible, because of greater demand and high cost of human labour. Intercropping has potential as a means of weed control because it offers the possibility of a mixture of crops capturing a great share of available resources than in monocropping. The wider row spacing in maize can be used to grow short duration legumes which not only will act as smother crop, but will give additional yield. Weed control approach involving intercropping, herbicides and non- chemical method in maize and maize based intercropping system is very important to provide effective and acceptable weed control for realizing high production (Shah et al., 2011). Besides, intercropping also reduces weeding cost and realizes higher total productivity of the system and monetary returns (Pandey and Prakash, 2002). But this system alone is not sufficient to ensure adequate weed control because of varied canopy coverage by the intercrops. Hence, an integrated approach is needed to control weeds through manual and chemical weeding in an intercropping system. Hence, the present study was taken up to find out suitable weed management practice in maize - blackgram intercropping system and to study the ability of intercrop to compete with weeds.

\section{Materials and Methods}

A field experiment was conducted at Tamil Nadu Agricultural University, Coimbatore during kharif 2013 to investigate the influence of intercropping systems and weed management practices on weed density, dry weight and weed control efficiency of maize under irrigated condition. The experiment was laid out in split plot design replicated thrice. The popular maize hybrid CO6 was used as test variety. Three intercropping systems viz., maize alone $\left(\mathrm{I}_{1}\right)$, maize + blackgram (1:1 ratio) $\left(\mathrm{I}_{2}\right)$ and maize + blackgram (2:2 ratio) $\left(\mathrm{I}_{3}\right)$ were evaluated under main plot and four weed management practices viz., unweeded check (Control) $\left(\mathrm{W}_{1}\right)$, Pendimethalin $0.75 \mathrm{~kg}$ $\mathrm{ha}^{-1}$ as pre emergence (PE) 3 DAS + one hand weeding 25 DAS $\left(\mathrm{W}_{2}\right)$, Imazethapyr $75 \mathrm{~g} \mathrm{ha}^{-1}$ as post emergence (POE) 25 DAS $\left(\mathrm{W}_{3}\right)$ and Pendimethalin $0.75 \mathrm{~kg} \mathrm{ha}^{-1}$ as PE 3 DAS + Imazethapyr $75 \mathrm{~g} \mathrm{ha}^{-1}$ as POE $25 \mathrm{DAS}\left(\mathrm{W}_{4}\right)$ were accommodated under subplot treatments. Observations on weed parameters viz., weed density, weed dry weight and weed control efficiency were recorded. Weed count was recorded by placing four quadrats of size $0.5 \mathrm{~m} \times 0.5 \mathrm{~m}$ in each plot and the weeds falling within the frames of the quadrat were counted, recorded and the mean values expressed in number $\mathrm{m}^{-2}$. The weeds falling within the frames of the quadrats were collected and dried in hot-air oven at $80^{\circ} \mathrm{C}$ for 72 hrs. Weed control efficiency (WCE) was calculated as per the procedure given by Mani et al., (1973) and expressed in percentage.

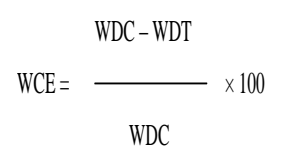

where

WDC - weed dry weight in unweeded control plot $\left(\mathrm{kg} \mathrm{ha}^{-1}\right)$

WDT - weed dry weight in treated plot $(\mathrm{kg}$ $\mathrm{ha}^{-1}$ )

\section{Results and Discussion}

Total weed density and total weed dry weight varied markedly due to intercropping systems and different weed management practices (Table 1). Among the intercropping systems, maize + blackgram intercropping (1:1) recorded lower density of total weeds (4.89 $\mathrm{m}^{-2}$ ) followed by maize + blackgram intercropping (2:2). Sole maize recorded the 
highest density of total weeds. The possible reason for this might be due to complete crop coverage and high plant density existed in intercropping system which had competitive advantage over the weeds and reduced the weed growth and development. Lower density and dry weight in intercropped plots indicated that sole crop cannot suppress the weed growth as compared to intercropped plots. Similar results are reported by Moody and Shetty (1981). Velayutham et al., (2002) also opined that intercrops provide efficient coverage of land resulting in suppression of weed growth.

Among the weed management practices, pendimethalin $0.75 \mathrm{~kg} \mathrm{ha}^{-1}+$ one HW 25 DAS recorded significantly lesser density and dry weight of total weeds. This was followed by application of pendimethalin $0.75 \mathrm{~kg} \mathrm{ha}^{-1}+$ imazethapyr $75 \mathrm{~g} \mathrm{ha}^{-1}$ as POE 25 DAS. This might be due to effective control of weeds at the germination phase through pre emergence application of soil applied herbicides and significant reduction at later growth stages as late germinating weeds were removed by hand weeding. Hand weeding or pre emergence herbicide could reduce the weed stand at early stages of crop growth was reported by Leela (2002) is in support of the present findings.

Weed control efficiency (WCE) indicates the magnitude of effective reduction of weed dry weight by weed control treatments over weedy check. The treatment combination involving maize + intercropping blackgram along with pre emergence application of pendimethalin $0.75 \mathrm{~kg} \mathrm{ha}^{-1}+$ one hand weeding on 25 DAS $\left(\mathrm{W}_{2}\right)$ and PE application of pendimethalin $0.75 \mathrm{~kg} \mathrm{ha}^{-1}+$ Imazethapyr $75 \mathrm{~g} \mathrm{ha}^{-1}$ as POE 25 DAS $\left(\mathrm{W}_{4}\right)$ recorded higher WCE (Table 2). More reduction of weed dry weight by reducing the weed density in these treatments resulted in higher WCE. Such reduction in weed dry weight and increase in WCE due to intercropping blackgram was reported by Ananthi (2013) is concomitant to the present result. Mynavathi (2007) also reported higher WCE of 94.69 per cent under pre emergence application of pendimethalin followed by one hand weeding in maize.

The maize grain yield was significantly influenced by intercropping systems and weed management practices. Sole maize recorded the highest grain yield of $5543 \mathrm{~kg} \mathrm{ha}^{-1}$ and was comparable with maize + blackgram intercropping (1:1) which recorded an yield of $5383 \mathrm{~kg} \mathrm{ha}^{-1}$ (Table 3). Maize + blackgram intercropping $(2: 2)$ recorded lower grain yield. The yield reduction due to intercropping blackgram (1:1) was less (3.52 per cent) comparing the sole maize yield, whereas the yield reduction due to maize + blackgram intercropping (2:2) was 7.57 per cent, indicating least effect of planting pattern of intercrops on the grain yield of maize. The yield increment in sole maize was only due to least competition for sunlight, space, water and nutrients while it was in intercrops having shading effect which curtailed efficient utilization of natural resources and restricted the growth of maize from initial stages to harvest resulted in yield competition in intercrop as reported by Yilmaz et al., (2008). Similar findings were also reported by Dwivedi et al., (2012). With regard to weed management practices, pendimethalin $0.75 \mathrm{~kg}$ $\mathrm{ha}^{-1}$ as PE + one HW 25 DAS recorded higher grain yield $\left(6546 \mathrm{~kg} \mathrm{ha}^{-1}\right)$ followed by pendimethalin $0.75 \mathrm{~kg} \mathrm{ha}^{-1}+$ imazethapyr $75 \mathrm{~g}$ $\mathrm{ha}^{-1}$ as POE 25 DAS (6085 $\left.\mathrm{kg} \mathrm{ha}^{-1}\right)$.

The interaction between intercropping systems and weed management practices on maize grain yield was significant. The highest grain yield $\left(5755 \mathrm{~kg} \mathrm{ha}^{-1}\right)$ was recorded under the treatment combination sole maize with pendimethalin $0.75 \mathrm{~kg} \mathrm{ha}^{-1}$ as $\mathrm{PE}+$ one $\mathrm{HW}$ 25 DAS followed by the treatment 
combination maize + blackgram intercropping at $1: 1$ ratio with pendimethalin $0.75 \mathrm{~kg} \mathrm{ha}^{-1}$ as $\mathrm{PE}+$ one HW 25 DAS. The least grain yield $\left(2943 \mathrm{~kg} \mathrm{ha}^{-1}\right)$ was obtained under maize + blackgram intercropped at 2:2 ratio without weeding. The yield increase could be attributed to the reason that herbicide application might have killed the weeds at germination phase devoiding competition for crop growth from the inception of germination of the crop and hand weeding on 25 DAS lasting its efficiency at later growth stages. The results are in accordance with the findings of Singh and Singh (2009) who have observed that pre emergence application of pendimethalin $250 \mathrm{~g} \mathrm{ha}^{-1}$ followed by one hand weeding on 45 DAS produced maximum pod and haulm yield of groundnut when compared to farmers' practice of hand weeding twice.

Table.1 Effect of intercropping and weed management practices on total weed density, weed dry weight and weed control efficiency in maize hybrid at 40 DAS

\begin{tabular}{|c|c|c|}
\hline Treatment & $\begin{array}{l}\text { Total weed } \\
\text { density(No. } \\
\left.\text { m }^{-2}\right)\end{array}$ & $\begin{array}{l}\text { Total weed } \\
\text { dry weight }(g \\
\left.\mathbf{m}^{-2}\right)\end{array}$ \\
\hline \multicolumn{3}{|l|}{ Intercropping system } \\
\hline$I_{1}$ - Sole maize & $\begin{array}{c}5.64 \\
(29.8)\end{array}$ & $\begin{array}{c}4.82 \\
(21.22)\end{array}$ \\
\hline$I_{2}-$ Maize + Black gram (1:1) $(60 \times 25 \mathrm{~cm})$ & $\begin{array}{c}5.12 \\
(24.24)\end{array}$ & $\begin{array}{c}4.62 \\
(19.30)\end{array}$ \\
\hline$I_{3}-$ Maize + Black gram (2:2) $(30 / 90 \mathrm{~cm})$ & $\begin{array}{c}4.89 \\
(21.95)\end{array}$ & $\begin{array}{c}4.49 \\
(18.20)\end{array}$ \\
\hline SEd & 0.05 & 0.03 \\
\hline $\mathrm{CD}(\mathbf{P}=\mathbf{0 . 0 5})$ & 0.15 & 0.09 \\
\hline \multicolumn{3}{|l|}{ Weed management practices } \\
\hline $\mathrm{W}_{1}$-Weedy check & $\begin{array}{c}10.04 \\
(98.87)\end{array}$ & $\begin{array}{c}7.64 \\
(56.42)\end{array}$ \\
\hline $\mathrm{W}_{2}$-Pendimethalin $0.75 \mathrm{~kg} \mathrm{ha}^{-1}+$ one HW 25 DAS & $\begin{array}{c}3.89 \\
(13.11)\end{array}$ & $\begin{array}{c}2.45 \\
(4.02)\end{array}$ \\
\hline W3 -Imazethapyr $75 \mathrm{~g} \mathrm{ha}^{-1}$ as POE 25 DAS & $\begin{array}{c}4.74 \\
(20.47)\end{array}$ & $\begin{array}{c}3.37 \\
(9.33)\end{array}$ \\
\hline $\begin{array}{l}\text { W4 -Pendimethalin } 0.75 \mathrm{~kg} \mathrm{ha}^{-1}+\text { Imazethapyr } 75 \mathrm{~g} \mathrm{ha}^{-1} \text { as } \\
\text { POE } 25 \text { DAS }\end{array}$ & $\begin{array}{c}4.35 \\
(16.94)\end{array}$ & $\begin{array}{c}3.24 \\
(8.50)\end{array}$ \\
\hline SEd & 0.06 & 0.04 \\
\hline $\mathrm{CD}(\mathbf{P}=\mathbf{0 . 0 5})$ & 0.15 & 0.08 \\
\hline Interaction & NS & NS \\
\hline
\end{tabular}

Figures in the parentheses are original values; values are transformed into square root transformation 
Table.2 Effect of intercropping and weed management practices on weed control efficiency in maize hybrid

\begin{tabular}{|c|c|c|}
\hline Treatment & 40 DAS & 60 DAS \\
\hline $\mathbf{I}_{\mathbf{1}} \mathbf{W}_{\mathbf{1}}$ & - & - \\
\hline $\mathbf{I}_{\mathbf{1}} \mathbf{W}_{\mathbf{2}}$ & 90.1 & 89.7 \\
\hline $\mathbf{I}_{\mathbf{1}} \mathbf{W}_{\mathbf{3}}$ & 79.0 & 82.7 \\
\hline $\mathbf{I}_{\mathbf{1}} \mathbf{W}_{\mathbf{4}}$ & 81.4 & 87.6 \\
\hline $\mathbf{I}_{\mathbf{2}} \mathbf{W}_{\mathbf{1}}$ & - & - \\
\hline $\mathbf{I}_{\mathbf{2}} \mathbf{W}_{\mathbf{2}}$ & 92.9 & 92.8 \\
\hline $\mathbf{I}_{\mathbf{2}} \mathbf{W}_{\mathbf{3}}$ & 82.7 & 84.1 \\
\hline $\mathbf{I}_{\mathbf{2}} \mathbf{W}_{\mathbf{4}}$ & 85.2 & 91.8 \\
\hline $\mathbf{I}_{\mathbf{3}} \mathbf{W}_{\mathbf{1}}$ & - & - \\
\hline $\mathbf{I}_{\mathbf{3}} \mathbf{W}_{\mathbf{2}}$ & 92.8 & 93.8 \\
\hline $\mathbf{I}_{\mathbf{3}} \mathbf{W}_{\mathbf{3}}$ & 84.8 & 86.5 \\
\hline $\mathbf{I}_{\mathbf{3}} \mathbf{W}_{\mathbf{4}}$ & 85.3 & 92.0 \\
\hline
\end{tabular}

Data not analyzed statistically

Table.3 Effect of intercropping and weed management practices on grain yield $\left(\mathrm{kg} \mathrm{ha}^{-1}\right)$ of maize hybrid

\begin{tabular}{|c|c|c|c|c|}
\hline Treatment & $\mathbf{I}_{1}$ & $\mathbf{I}_{2}$ & $\mathbf{I}_{3}$ & Mean \\
\hline$W_{1}$-Weedy check & 3038 & 3039 & 2943 & 3007 \\
\hline $\begin{array}{l}\mathrm{W}_{2} \text {-Pendimethalin } 0.75 \mathrm{~kg} \mathrm{ha}^{-1}+\text { one HW } 25 \\
\text { DAS }\end{array}$ & 6755 & 6737 & 6147 & 6546 \\
\hline W3 -Imazethapyr $75 \mathrm{~g} \mathrm{ha}^{-1}$ as POE 25 DAS & 6051 & 5798 & 5740 & 5863 \\
\hline $\begin{array}{l}\text { W4 -Pendimethalin } 0.75 \mathrm{~kg} \mathrm{ha}^{-1}+ \\
\text { Imazethapyr } 75 \mathrm{~g} \mathrm{ha}^{-1} \text { as POE } 25 \text { DAS }\end{array}$ & 6330 & 5960 & 5965 & 6085 \\
\hline \multirow[t]{2}{*}{ Mean } & 5543 & 5383 & 5199 & \\
\hline & SEd & $\underset{(P=0.05)}{C D}$ & & \\
\hline I & 60 & 175 & & \\
\hline W & 78 & 183 & & \\
\hline I at $\mathbf{W}$ & 131 & 319 & & \\
\hline W at I & 117 & 227 & & \\
\hline
\end{tabular}

In conclusion, the results of the experiment revealed that maize + blackgram intercropping along with pendimethalin 0.75 $\mathrm{kg} \mathrm{ha}^{-1}$ as PE 3 DAS + one HW 25 DAS can lower the weed density and dry weight during critical stage of the crop growth sole maize with pendimethalin $0.75 \mathrm{~kg} \mathrm{ha}^{-1}$ as PE 3 DAS
+ one HW25 DAS recorded higher grain yield followed by maize + blackgram intercropping at 1:1 ratio along with pendimethalin $@ 0.75 \mathrm{~kg} \mathrm{ha}^{-1}$ as PE on 3 DAS + one hand weeding on 25 DAS and both were comparable with each other. 


\section{References}

Ananthi, T. 2013. Influence of intercropping systems, mycorrhizal inoculation and fertilizer levels on the productivity of maize based cropping system. Ph.D., Thesis, Tamil Nadu Agricultural Univ., Coimbatore, Tamil Nadu, India.

Dogan, M.N., A. Unay, O. Boz and F. Albay. 2004. Determination of optimum weed control timing in maize (Zea mays L.). Turk J. Agron., 28: 349-354.

Dwivedi, S.K., G.K. Shrivastava, A.P. Singh and R. Lakpale. 2012. Weeds and crop productivity of maize + blackgram intercropping system in Chhattisgarh plains. Indian J. Weed Sci., 44(1): 2629, 2012

Leela, C. 2002. Weed dynamics and crop productivity as influenced by preparatory tillage and weed management methods in sunflowermaize cropping system. M.Sc. Ag Thesis, Tamil Nadu Agricultural University, Coimbatore, India.

Mani, V.S., M.L. Mala, K.C. Gautam and Bhagavandas. 1973. Weed killing chemicals in potato cultivation. Indian Fmg., 23(1): 17-18.

Moody, K. and S.V.R. Shetty. 1981. Weed management in intercropping systems. In: Proceedings of International Workshop on Intercropping. 10-13 January, 1999. ICRISAT, Hyderabad, pp. 229-237.
Mynavathi, V.S. 2007. Evaluation of manually operated weeders in irrigated maize. M.Sc. Ag. Thesis. Tamil Nadu Agricultural University. Coimbatore. Tamil Nadu, India

Mynavathi, V.S., N.K. Prabhakaran and C. Chinnusamy. 2008. Evaluation of mechanical weeders in irrigated maize (Zea mays). Indian J. Weed Sci., 40(3\&4):210-213.

Pandey A. K., and V. Prakash. 2002. Weed management in maize and soybean intercropping system. Indian J. Weed sci., 34: 67-69.

Shah, S.N., J.C. Shroff, R.H. Patel and V.P. Usadadiya. 2011. Influence of intercropping and weed management practices on weed and yields of maize. Intl. J Sci., and Nature. 2(1): 47-50.

Singh, H. and S. Singh. 2009. Weed management and soil micro organisms studies in irrigated summer groundnut (Arachis hypogaea L.). Indian J. Weed Sci., 41 (1\&2): 103-107.

Velayutham, A., M. Ali and V. Veerabadran. 2002. Influence of intercropping system and weed management. Madras Agric. J., 89(1-3): 59-62.

Yilmaz, S., Atak, M. and Erayman, M. 2008.Identification of advantages of maize-legume intercropping over solitary cropping through competition indices in the East Mediterranean Region. Turk. J. Agric., 32: 111-119.

\section{How to cite this article:}

IshaqRahimi, M. Mohamed Amanullah, T. Ananthi and Mariappan, G. 2019. Influence of Intercropping and Weed Management Practices on Weed Parameters and Yield of Maize. Int.J.Curr.Microbiol.App.Sci. 8(04): 2167-2172. doi: https://doi.org/10.20546/ijcmas.2019.804.254 